\title{
MORPHEME-BASED RENDAKU AS A RHYTHMIC STABILIZER in EASTERn OLD JAPANESE POETRY
}

\author{
John KUPCHIK \\ Kyoto University - JSPS \\ johnkupchik@gmail.com
}

\begin{abstract}
This paper explores the functions of morpheme-based rendaku, or "sequential voicing", in Eastern Old Japanese poetry, with a focus on its function of maintaining rhythmic stability in poetic verse. It is argued that this function is implemented to avoid a hypermetrical line when no adjacent vowels exist as candidates for synchronic elision. Furthermore, a comparison with synchronic vowel elision is conducted. Based on the results, it is argued that morpheme-based rendaku is preferred to synchronic vowel elision when both are available options for maintaining the rhythmic stability of a line. Linguistic constraints blocking morpheme-based rendaku are also discussed to explain hypermetrical examples with potential, yet unrealized, morpheme-based rendaku.
\end{abstract}

\section{Keywords}

phonology; phonetics; Old Japanese; rendaku; poetry

\section{Izvleček}

Raziskava se osredotoča na funkcijo t.i. "sequential voicing" ali zvenečnjenja na nivoju morfemov v stari vzhodno-japonski poeziji, in sicer daje poudarek funkciji, ki ohranja ritmično stabilnost verza. Avtor pokaže, da se v primeru, ko ni okoliških samoglasnikov, ki bi sodelovali pri sinhronem izpadu samoglasnikov, $\mathrm{z}$ uporabo te funkcije izognemo hipermetrični vrstici. Vzporedno avtor primerja zvenečnjenje in sinhroni izpad samoglasnikov in ugotovi, da je v primeru, ko sta za ohranjanje ritmične stabilnosti možni obe vrsti posredovanja, zvenečnjenje bolj željena izbira. Nazadnje so analizirane lingvistične omejitve, ki preprečujejo uporabo zvenečnjenja, in s tem tudi hipermetrični primeri s hipotetičnim obstojem zvenečnjenja.

\section{Ključne besede}

fonologija; fonetika; stara japonščina; zvenečnjenje; poezija 


\section{Introduction ${ }^{1}$}

The Eastern Old Japanese (EOJ) dialects were spoken in the first half of the $8^{\text {th }}$ century CE in Kamitukeno, Sagamu, Simotukeno, Muzasi, Pitati, Michinöku, Simotupusa, and Kamitupusa provinces ${ }^{2}$, all of which were located in the Eastern (Azuma) region of Japan. The language is markedly different in many aspects of grammar and lexicon compared to Western Old Japanese (WOJ), Central Old Japanese, and Töpo-Suruga Old Japanese, all of which were spoken in Japan at the same time.

EOJ is attested exclusively in poetry in books 14 and 20 of the Man'yōsh $\bar{u}$ poetry anthology, and has been an important subject of interest for Japanese linguists for over half a century, beginning with the early seminal works by Fukuda (1965), Hōjō (1966), and Mizushima (1972, 1984a, 1984b, 1986) and continuing on in recent studies by Mizushima (1996, 2003, 2005, 2009), Vovin (2005, 2009a, 2009b), and Kupchik (2011). Also notable are the important commentaries by Nakanishi $(1981,1983)$, Omodaka (1984a, 1984b), Itō (1997, 1998), and Aso (2011). Long heralded as a language that contains crucial pieces of information necessary for the reconstruction of Proto-Japonic and Proto-Japanese, much previous linguistic research has focused on its array of retentions, some of which are shared with Ryukyuan languages (Pellard, 2008). However, an equally interesting, yet seldom discussed, characteristic of the language is that it displays some of the earliest attested examples of rendaku, or "sequencial voicing." In Modern Japanese rendaku is a morphophonological process that voices the initial consonant of the second element of a compound. For example, when ao "blue" and sora "sky" combine the output is not aosora but aozora. There are phonological and lexical restrictions on Modern Japanese rendaku and it is not completely regular. In EOJ there are two types of rendaku: morpheme-based and process-based. These are described in Section 2 of this paper.

The goal of this paper is to explore the functions of morpheme-based rendaku in EOJ through a comprehensive analysis of the corpus. In particular, attention will be paid to its use in speech rhythm, and how it interacts with synchronic vowel elision in hiatus contexts. A comparison between morpheme-based rendaku and synchronic vowel elision will also be made to see if their effects in speech rhythm are different, or if one is preferred over the other for any particular function.

\footnotetext{
${ }^{1}$ Research for this work was supported by Grants-in-Aid for Scientific Research (Kakenhi) \#23.11784 from the Japan Society for the Promotion of Science (JSPS).

${ }^{2}$ I write all province names in their reconstructed $8^{\text {th }}$ century pronunciations (note that $/ \mathrm{o} /$ represents a schwa). These correspond to the present-day names Kōzuke 上野, Sagami 相模, Shimotsuke 下野, Musashi 武蔵, Hitachi 常陸, Mutsu 陸奥, Shimōsa 下総 and Kazusa 上総, respectively.
} 


\subsection{Methodology}

Kupchik (2011, pp. 871-1013)'s annotated EOJ corpus was used for this study. The total corpus used consists of 234 poems from Man'yōsh $\bar{u}$ books 14 and 20, most of which contain 31 syllables in a syllabic rhythm of 5-7-5-7-7. Any of the poems were marked if they showed morpheme-based rendaku or hypermetricality, and then digital searches were conducted to find all examples for each particular type. Examples are written in the IPA, and follow Kupchik (2011, pp. 29-482)'s reconstruction of EOJ phonology and phonetics. Logographic morphemes are written in italics. The original Man'yogana ${ }^{3}$ orthography is also given. Textual attestations are given in the following format:

\section{(book:poem.line - province)}

For example, if the example is from Man'yōshī book 14, poem 3384, line 4, from Simotupusa province, it will be shown as (14:3384.4 - Simotupusa). Sequential lines are marked with a hyphen, while non-sequential lines are separated by a backslash. Thus 14:3506.1-2/5 indicates the poem is from book 14, poem 3506, lines 1, 2 and 5 (but not 3 or 4 ).

Some poems have no overt province attribution. These are called "unknown dialect" poems, abbreviated as UD.

\subsection{The rhythm of EOJ poetry}

EOJ poetry is almost exclusively in the tanka style, which most often consists of five lines of verse in a sequence of 5-7-5-7-7 syllables. Hypermetrical lines are permitted, at least superficially, but almost never in excess of one syllable ${ }^{4}$. Depending on the scribe or dialect hypermetrical lines may have either been firmly restricted or conditionally permitted.

In order to maintain a stable metrical rhythm, two strategies are used. First, we find quite frequently the synchronic ${ }^{5}$ elision of one of two adjacent vowels in hiatus across word boundaries, with $\mathrm{V}_{2}$ elision being the most prominent (Kupchik, 2011, p. 483), which is typologically rare (Casali, 1997, 1998). I will refer to this as synchronic vowel elision (SVE) in this paper. The second strategy is the use of morpheme-based rendaku to contract the line.

\footnotetext{
${ }^{3}$ Man'yoggana is a system of Chinese characters used for either their meaning or sound values. Most of the EOJ poems are written in purely phonographic Man'yōgana, though a small set of logographic characters appear in some poems as well.

${ }^{4}$ One example with nine syllables in a line is found in 14:3423.5, from Kamitukeno province.

${ }^{5}$ It is important to distinguish between synchronic and diachronic elisions. Synchronic elisions are those that occur optionally at the boundary between two separate word-forms and they are not lexicalized. Diachronic elisions occur in compounds, verbal morphophonology, and lexicalized collocations in the language, and they are completely lexicalized. Many diachronic elisions are shared with Western Old Japanese and certainly go back at least to Proto-Japanese times.
} 


\section{Types of rendaku}

In this paper I distinguish between two types of rendaku: process-based and morpheme-based. Process-based rendaku is described in section 2.1, while morphemebased rendaku is described in section 2.2.

\subsection{Process-based rendaku}

Process-based rendaku involves reduplicating the root and prenasalizing and voicing the onset of the reduplicant. It has a function of pluralization, and there is no derivable morpheme from the resulting prenasalized onset of the reduplicant. This is only attested a few times. An example is shown below.

(i) 20:4391.1-3 - Simotupusa 久尔具尔乃 / 夜之里乃加美尔 / 奴作麻都理 kuni- 'guni-nə / yasiri-nə kami-ni / nusa matur-i province-REDUP-GEN / shrine-GEN deity-DAT / paper_offering offer-INF "I make paper offerings to the deities in the shrines of [many] provinces."

The reduplication itself is not adequate to indicate plurality - indeed, without the rendaku prenasalization and voicing, reduplication usually has an iterative function in EOJ (Kupchik, 2011, p. 566). Due to the fact process-based rendaku is not used to stabilize the rhythm of a line of poetry, it will not be discussed further in this paper.

\subsection{Morpheme-based rendaku (MBR)}

Morpheme-based rendaku (henceforth abbreviated as MBR) refers to the wordboundary contraction of the vowel of a nasal-initial syllable of a grammatical morpheme or word form (in the case of the copula $n$-), which in turn fuses with the following voiceless onset, prenasalizing and voicing it in the output. Prenasalizedvoiced onsets are restricted from participating, as they are already prenasalized and voiced $^{6}$. This is extremely useful when confronted with a fairly rigid meter and no other allowable contractive processes other than SVE. MBR is well attested in all dialects of Old Japanese and it is the historical source of many of the rendaku forms found in Modern Japanese.

The grammatical morphemes and word-forms that may participate in MBR are shown in Table 1 below. While they are not numerous, they are some of the most frequently attested morphemes in the corpus.

\footnotetext{
${ }^{6} \mathrm{EOJ}$ is a language that has the uncommon contrast between voiceless and prenasalized-voiced obstruents, but no plain voiced obstruents.
} 
Table 1: Grammatical morphemes that trigger morpheme-based rendaku

\begin{tabular}{|l||}
\hline Dative/Locative $-n i$ \\
\hline Genitive $-n ə$ \\
\hline Copula-infinitive $n-i$ \\
\hline Copula-adnominal $n$-ə \\
\hline Demonstrative pronoun “this" kanə \\
\hline
\end{tabular}

All contracted rendaku forms of the above morphemes are well attested except kənə's form $k \partial^{n}-$, which is only attested once. An example of each is given below in examples (1) - (5).

(1) 14:3506.1-2/5 - UD

尔比牟路能 / 許騰伎尔伊多礼婆/見延奴已能許呂

nipi muro-nə / kən -dəki-ni itar-e- ${ }^{\mathrm{m}} \mathrm{ba}^{7} / \mathrm{mi}$-ye-n-u kənə kərə

new house-GEN / this-time-LOC arrive-EV-CONJ / see-PASS-NEG-ATTR this time

"Since the time of the new house has arrived, this is a time when I am unable to see you."

The underlying form of line 2 in example (1) is /kənə təki-ni itar-e- ${ }^{\mathrm{m}} \mathrm{ba} /$.

(2) 20:4368.1-2 - Pitati

久自我波々 / 佐氣久阿利麻弓

$\mathrm{ku}^{\mathrm{n}} \mathrm{zi}^{\mathrm{g}}{ }^{\mathrm{g}}$-gapa pa / sake-ku ari-mat-e

PN-GEN-river TPT / be.safe-AVINF ITER-wait-IMP

"Be waiting for me safely, [at] $\mathrm{Ku}^{\mathrm{n}} \mathrm{zi}$ river!"

The underlying form of line 1 in example (2) is $/ \mathrm{ku}^{\mathrm{n}} \mathrm{zi}$-nə gapa pa/.

(3) 14:3537b.1-2 - UD

宇麻勢胡之 / 牟伎波武古麻能

uma-se- ${ }^{\mathrm{y}}$-gos-i / mu gi pam-u koma-no

horse-fence-LOC-cross-INF / grain munch-ATTR stallion-COMP

"Like a stallion that crosses the horse-fence to munch on grain."

The underlying form of line 1 in example (3) is /uma-se-ni kos-i/.

\footnotetext{
${ }^{7}$ There is another interpretation of this line mentioned by Mizushima (1986, p. 307), in which the first three syllables, $k \partial^{n} d \partial k i$, are a reduction of $k \partial-n \partial t \partial k i$ "silkworm-GEN time". The problem with this is "silkworm; child" is $k o$, not $k$. We would therefore have to conclude the vowel change was due to a regressive assimilation to the vowel in təki "time", but I am skeptical due to the fact $k \partial^{n} d \partial k i$ is attested just once in all of the Old Japanese corpus. Furthermore, while progressive vowel assimilations are well attested in the EOJ corpus, other examples of a regressive vowel assimilation are not attested.
} 
(4) 14:3412.4-5 - Kamitukeno

可奈師家兒良尔 / 伊夜射可里久母

kanasi-ke ko-ra-ni / iya ${ }^{\mathbf{n}}$-zakar-i-k-umo

be.adorable-AVATTR girl-DIM-DAT /

more.and.more COP.INF-be.far.from-INF-go-EXCL

"I am going further and further away from my adorable girl!"

The underlying form of line 5 in example (4) is /iya n-i sakar-i-k-umo/.

(5) $14: 3489.5-$ UD

左祢度波良布母

sa-ne ${ }^{\mathbf{n}}$-do parap-umo

LOC-sleep.NML COP.ATTR-place clear.away-EXCL

"I'll clear away a place for us to sleep."

The underlying form of the line in example (5) is /sa-ne n-ə to parap-umo/.

Normally we only find one occurrence of MBR in a line, but there is one extreme case where the underlying line is nine syllables and two instances of MBR are used to contract it into seven syllables, shown below in example (6).

(6) 14:3497.1-2 - UD

可波加美能 / 祢自路多可我夜

kapa kami-nə / ne- ${ }^{\text {n }}$-ziro taka ${ }^{\text {" }}$-gaya ${ }^{8}$

river upper.part-GEN / root-GEN-white high COP.ATTR-grass

"Like the tall grass with white roots in the upper part of the river."

The underlying form of line 2 in example (6) is /ne-nə siro taka n-ə kaya/.

It should also be noted that MBR only occurs when an underlying line is hypermetrical and it never occurs at the boundary between two lines. Due to this, we can conclude its primary function was to stabilize the rhythm of a single line of verse.

\subsubsection{Evidence for the lack of lexicalization of MBR}

To show that MBR is not implemented unless needed, examples are given below in (7) - (11) where the underlying line is metrical, and consequently no MBR occurs. While, due to the small size of the corpus, it is difficult to find examples containing all of the same morphemes as in the MBR examples, the following examples are phonologically similar as well as morphosyntactically similar.

\footnotetext{
${ }^{8}$ While I mark the morpheme boundaries between the prenasalization and the following onset in order to clearly indicate the morphemes involved (i.e. /" -ziro/ "GEN-white"), we must remember prenasalized voiced consonants were unit phonemes. Thus the post-rendaku forms are completely fusional and consequently should be understood as being portmanteau morphs.
} 
(7) 14:3460.3-5 - UD

尔布奈未尔 / 和我世乎夜里弓 / 伊波布許能戸乎

nipu nami-ni / wa- ${ }^{\mathrm{g}}$ ga se-wo yar-i-te / ipap-u kənə to-wo

new taste.NML-LOC / 1.S-POSS lover-ACC send-INF-SUB /

pray-ATTR this door-ACC

"I pray to this door after sending my husband away during the new [rice] tasting."

(8) 14:3369.1-4 - Sagamu

阿之我利乃 / 麻万能古須氣乃 / 須我麻久良 / 安是加麻可左武

asi $^{1}$ gari-nə / mama-nə ko-suke-nə / su ${ }^{\mathrm{n}}$ ga-makura / a ${ }^{\mathrm{n}}$ ze ka mak-as-am-u

PN-GEN / cliff-GEN DIM-sedge-GEN / sedge-pillow /

why QPT use.as.a.pillow-HON-TENT-ATTR

"Why would you use a sedge pillow made of sedge from the cliffs of Asigari as a pillow?"

(9) 14:3514.4-5 - UD

和礼左倍尔 / 伎美尔都吉奈那 / 多可袮等毛比弓

ware sape n-i / kimi-ni tuk-i-n-ana / taka ne to mop-i-te

1.S RPT COP-INF / lord-LOC attach-INF-PERF-DES / high peak COP think-INF-SUB

"I, too, would like to be with you, my lord. I think of you as a high peak."

(10) 14:3350.4-5 - Pitati

伎美我美家思志 / 安夜尔伎保思母

kimi- ${ }^{\mathrm{g}}$ ga mi-kesi si / aya n-i ki posi-mo

lord-POSS HON-clothes FPT / extremely COP-INF wear.NML be.desired-EXCL

"I so desperately want to put on my lord's clothes!"

(11) 20:4420.4-5 - Muzasi

安我弓等都氣呂 / 許礼乃波流母志

a- ${ }^{\mathrm{j}}$ ga te-tə tuke-rə / kəre n-ə paru məs-i

REFL-POSS hand-COM affix-IMP / this COP-ATTR needle hold-INF

"Put it together again with your own hands, holding this needle."

\subsubsection{Unrealized MBR in hypermetrical lines}

While there are dozens of cases of unrealized SVE in a hypermetrical line, there are only a few cases where MBR seems to be possible, but remains unrealized in a hypermetrical line. An example is shown in (12) below.

(12) 14:3418.5 - Kamitukeno

伊麻波伊可尔世母

ima pa ika n-i se-m-o

now TPT how COP-INF do-TENT-ATTR

"Whatever shall I do now?"

In example (12) we find a hypermetrical line even though theoretically the copulainfinitive $n-i$ could be contracted to $\left.{ }^{\mathrm{n}}\right]$, and voice the following onset to [z]. However, I could not find a single example of the onset of se- "do" becoming prenasalized to [ $\left.{ }^{\mathrm{n}} \mathrm{z}\right]$ in EOJ or WOJ, so it is possible that there was a lexical prohibition on this root 
becoming prenasalized. We should note that SVE in the sequence [ai] also does not occur in example (12).

In example (13) below we find a hypermetrical line 5, but no MBR occurring between the copula-infinitive $n-i$ and the emphatic particle si to create an output of [ ${ }^{\mathrm{zi}}$ ]. SVE in the sequence [ia] also does not occur in this example.

(13) 20:4351 - Kamitupusa

多泚已呂母 / 夜倍伎可佐祢弓 / 伊努礼等母 /

奈保波太佐牟之/ 伊母尔志阿良袮婆

ta ${ }^{\mathrm{m}}$ bi kərəmo / ya-pe ki-kasane-te / i-n-ore- ${ }^{\mathrm{n}}$ dəmo /

napo $\mathrm{pa}^{\mathrm{n}}$ da samu-si / imo n-i si ar-an-e- ${ }^{\mathrm{m}}$ ba

journey garment / eight-CL wear.INF-pile.INF-SUB / sleep-sleep-EV-CONC /

still skin be.cold-FIN / darling COP-INF EPT exist-NEG-EV-CONJ

"Although I do sleep wearing the many layers [of my] travel garment, still my bare skin is cold, because my darling is not here!"

As there are no attested examples of a particle undergoing MBR, they were likely restricted from participating in the process, much like words with voiced onsets and the verb se- "do". Further strengthening this idea is example (14) below, where we see the same string of morphemes ( $n-i$ si ar- "COP-INF EPT exist-") with the occurrence of SVE, but not MBR.

(14) 20:4393.1-2 - Simotupusa

於保伎美能 / 美許等尔作例波

opo kimi-nə / mikətə n-i s-ar-e- ${ }^{\mathrm{m}}$ ba

great lord-GEN / command COP-INF EPT-exist-EV-CONJ

"When [my] great lord's command came to be."

\subsubsection{Hypermetricality in the wake of MBR}

There is one attestation in the corpus where the application of MBR is not enough to make a line metrical. This example is given in (15) below, where both lines are hypermetrical. There are a few interesting things to note about this example. First, there is nothing to contract in line $1-$ the conditions necessary for MBR or SVE to occur are non-existent. Second, in line 2 both MBR and SVE are possible, but only MBR occurs. It is unclear why the adjacent vowels in the sequence kumo ar- remain in the output. It is possible that some lexical items were not permitted to undergo SVE (recall, also, the point that there appears to be a restriction on se- "do" and particles participating in MBR). Further to this point, as far as I can tell there are no attestations of kumo "cloud" losing its final vowel or eliding an adjacent vowel in any Old Japanese text. The verb ar- "exist" is similarly unattested in OJ with a synchronically elided vowel. 
(15) 14:3516.1-2 - UD

對馬能祢波 / 之多具毛安良南敷

tusima-nə ne pa / sita- ${ }^{\mathrm{g}}$-gumo ar-an-ap-u

PN-GEN peak TPT / below-GEN-cloud exist-NEG-ITER-FIN

"There are no clouds below the peaks of Tusima."

\subsubsection{Lexical parallels to MBR}

A few lexical morphemes are also attested behaving similar to MBR. These nouns lose the vowel in their nasal-initial syllable when combined with another word. This is a rare phenomenon in EOJ, but one relevant to the present discussion. One example is yumi "bow". An example of its contracted form $y u^{n}$ - is provided below in example (16).

(16) $14: 3567$ - UD

於伎互伊可婆 / 伊毛婆麻可奈之 /

母知互由久 / 安都佐能由美乃 / 由都可尔母我毛

ok-i-te ik-a ${ }^{\mathrm{m}} \mathrm{ba}$ / imo pa ma kanasi /

mot-i-te yuk-u / a dusa-nə yumi-nə / yu ${ }^{\text {n }}$-duka n-i mo ${ }^{\text {ng }}$ gamo

leave.behind-INF-SUB go-COND / darling TPT so be.sad.FIN /

hold-INF-SUB go-ATTR / catalpa-GEN bow-GEN / bow-grip COP-INF DPT

"If [I] go leaving [her] behind, my darling will be so sad. I wish she could be

the grip of the catalpa bow, which I will take with me."

However, this form is probably lexicalized, as the form yumi tuka "bow grip" is unattested in OJ. Thus it is not a good analog to MBR, which occurs synchronically.

A more intriguing example is miti "road", which we often find synchronically contracted to ${ }^{n} d i$ as the second part of many compounds. This is more relevant to MBR as this contraction only occurs when needed to stabilize the rhythm of the line. This is shown, for example, in example (17):

(17) 14:3405a.3 - Kamitukeno

可波治尔毛

kapa- ${ }^{\mathrm{n}} \mathbf{d i}-\mathrm{ni}$ mo

river-road-LOC FPT

"Even on the river road"

The underlying form of example (17) is [kapa-miti-ni mo], with six syllables instead of the rhythmically ideal five. By contracting miti into ${ }^{n} d i$ the desired five syllable rhythm for the line is achieved. This word is not contracted unless metrically required, as demonstrated in example (18), which is already metrical with its underlying five syllables that surface in the output: 
(18) 14:3477.1 - UD

安都麻道乃

$a^{n}$ duma miti-nə

PN road-GEN

"Of Aduma road"

An alternate analysis of miti's contracted form ${ }^{n} d i$ is presented by Vovin (2009c, p. 49 ; 2010, p. 200), who segments it as $-^{n}-d i$ "-GEN-road" (a contraction of -na ti "id."), which would make it an example of MBR. I disagree with this analysis for the following reasons: miti "road" is often not preceded by the genitive -no when it is uncontracted and preceded by a nominal (such as a place name), as shown in example (18) above; $t i$ "road" is unattested preceded by an uncontracted genitive $-n \partial ; t i$ "road" does not appear at all outside of the compound ti-mata "road-fork", which is only attested logographically in WOJ, the place name 當芸麻知 $t a^{n}$ gima- $t i$ “Tagima Road” attested once in Kojiki Kayo 77, and possibly also naga-ti "long road", though that also seems to be only attested logographically. Also note the parallelism with yumi "bow" $\sim y u^{n}-d u k a$ "bow-grip", which shows an identical phonological contraction of [mit] > $\left[{ }^{\mathrm{n}} \mathrm{d}\right]$ in compounds. While historically the evidence for "road" being *ti in ProtoJaponic is strong, synchronically only miti and its contracted allomorph ${ }^{n} d i$ exist in EOJ.

\section{MBR or SVE: is one preferred over the other?}

The data suggests MBR is preferred over SVE. One piece of evidence can be seen in line 2 of example (1) above, as the adjacent vowels [ii] do not elide, but MBR occurs at the start of the line. Similarly, as mentioned before, MBR occurs in line 2 of example (15) above but no SVE occurs in the adjacent vowels [oa]. In addition, examples (19) and (20) below show MBR, but adjacent vowels remain in the output:

(19) 14:3527.4-5 - UD

伊伎豆久伊毛乎 / 於伎五伎努可母

iki-" -duk-u imo-wo / ok-i-te k-i-n-o kamo

breath-LOC-breathe-ATTR beloved_girl-ACC /

leave_behind-INF-SUB come-INF-PERF-ATTR EPT

"I left my darling weeping and came [here]!"

In example (19) we find the underlying form [iki-ni tuk-u] realized as $i k i^{-}{ }^{n} d u k-u$ due to the implementation of MBR, but no SVE of the following vowel sequence [ui]. Similarly, in example (20) below we find the underlying form [ura-ni tat-i] realized as $u r a-{ }^{n}$-dat-i due to the implementation of MBR, with no SVE in the preceding vowel sequence [eu]. 
(20) $14: 3552$ - UD

麻都我宇良尔 / 佐和恵宇良太知 / 麻比登其等 /

於毛抱須奈母呂 / 和賀母抱能須毛

matu- ${ }^{\mathrm{n}}$ ga ura-ni / sawawe ura- ${ }^{\mathrm{n}}$-dat-i / ma-pitə- ${ }^{\mathrm{n}}$-gətə /

omop-os-unam-ə rə / wa- ${ }^{\mathrm{g}} \mathrm{ga}$ mop-o-nəsu mo

pine-POSS bay-LOC / noisy tip-LOC-rise-NML / INT-people-word /

think-HON-TENT2-ATTR COP / 1.S-POSS think-ATTR-COMP FPT

"You surely think that people's rumors are like the noisiness rising to the tips

[of the tree branches] in the bay of pines. My thoughts are also like that."

Importantly, metrical lines with SVE along with unrealized MBR are unattested in the corpus. It should also be noted that there are no examples of a hypermetrical line with unrealized MBR (when the aforementioned restrictions on MBR are taken into account), but there are many examples of hypermetrical lines with unrealized SVE.

\section{Summary and conclusion}

This paper has given evidence that suggests the primary function of MBR was to stabilize the rhythm of a single line of verse. The evidence also suggests that MBR is preferred over SVE when both are available to contract a line into the ideal rhythm of the tanka verse. This patterns well with the fact that SVE is not strongly preferred over hypermetricality in the language.

Still, the question remains: why is there a preference for MBR over SVE? One possibility is that SVE and MBR have different stylistic functions in the language. The specific type of SVE found in EOJ quite possibly only occurred in poetic verse (there is no evidence to the contrary), while it seems MBR was something more central to the grammar, due to the fact it continues on in later forms of Japanese while SVE does not. In fact, historically rendaku becomes far more prevalent in Japanese as time goes on with morpheme-based and process-based rendaku eventually merging into one. Based on this, it is not unrealistic to conclude SVE was mainly a poetic device employed by scribes for verse composition, while MBR was a more basic element of the grammar more widely used in the language. Therefore, this hypothesis maintains MBR had grammatical primacy to stabilize the rhythm of verse, while SVE was a more artificial device used for the same effect mainly when the conditions necessary for MBR to occur were not met. It is unsurprising, then, that when both are equal candidates to stabilize the rhythm of a single line of verse, the primary device is preferred.

Another element that may be at play in these data is the cross-linguistic initialsyllable positional privilege (Beckman, 1998, pp. 50-58) which maintains there is a preference to retain initial syllables of words rather than final syllables. MBR preserves the initial syllable of words, while EOJ's SVE is mainly of the type that elides $\mathrm{V}_{2}$, which deletes the initial syllable of a word. However, it is difficult to explain the predominantly $\mathrm{V}_{2}$ elision operating in EOJ if the language really followed this typological trend. 


\section{Abbreviations}

\section{Linguistic terms}

MBR Morpheme-based rendaku

SVE Synchronic vowel elision

\section{Grammatical terms}

1.S First person singular pronoun

ACC Accusative case

ATTR Attributive marker

AVATTR Adjectival verb attributive

AVINF Adjectival verb infinitive

CL Classifier

COM Comitative case

COMP Comparative case

CONC Concessive gerund

CONJ Conjunctive gerund

COP Copula

DAT Dative case

DES Desiderative

DIM Diminutive

DPT Desiderative particle

EPT Emphatic particle

EV Evidential

EXCL Exclamative

FIN Final predication marker

FPT Focus particle

GEN Genitive case

HON Honorific

IMP Imperative

INF Infinitive

INT Intensifier

ITER Iterative

LOC Locative case

NEG Negative

NML Nominalizer

PASS Passive

PERF Perfective aspect

PN Place name

POSS Possessive case 


$\begin{array}{ll}\text { QPT } & \text { Question particle } \\ \text { REDUP } & \text { Reduplication } \\ \text { REFL } & \text { Reflexive } \\ \text { RPT } & \text { Restrictive particle } \\ \text { SUB } & \text { Subordinative gerund } \\ \text { TENT } & \text { Tentative mood } \\ \text { TENT2 } & \text { Second tentative mood } \\ \text { TPT } & \text { Topic particle }\end{array}$

\section{Languages}

$\begin{array}{ll}\text { COJ } & \text { Central Old Japanese }\left(8^{\text {th }} \text { century CE, central Yamato) }\right. \\ \text { EOJ } & \text { Eastern Old Japanese }\left(8^{\text {th }} \text { century CE, Azuma region }\right) \\ \text { PJ } & \text { Proto-Japanese } \\ \text { TS } & \begin{array}{l}\text { Töpo-Suruga Old Japanese }\left(8^{\text {th }} \text { century CE, Töpotuapumi (=Tōtōmi) }\right. \\ \text { and Suruga provinces })\end{array} \\ \text { UD } & \text { Azuma poems from an unspecified dialect } \\ \text { WOJ } & \text { Western Old Japanese }\left(8^{\text {th }} \text { century CE, Nara region }\right)\end{array}$

\section{References}

Aso, M. (2011). Man'yōshū zenka kōgi. Kan daijūsan kan daijūyon [A commentary on all Man'yōshū poems. Books 13 14]. Tokyo: Kasama Shoin.

Beckman, J. (1998). Positional faithfulness. PhD dissertation, University of Massachusetts at Amherst.

Casali, R. (1997). Vowel elision in hiatus contexts: Which vowel goes? Language 73(3): 493533.

Casali, R. (1998). Resolving hiatus. New York: Garland.

Fukuda, Y. (1965). Nara jidai Azuma hōgen no kenkyū [A study of Nara period Azuma Dialect]. Tōkyō: Kazama shoin.

Hōjō, T. (1966). Jōdai tōgoku hōgen no kenkyū [A study of the dialect of the eastern province of the ancient period]. Tōkyō: Maruzen.

Itō, H. (1997). Man'yōshū shakuchū, 7 [Man'yōshū annotated commentary, vol 7]. Tokyo: Shūeisha.

Itō, H. (1998). Man'yōshū shakuchū, 10 [Man'yōshū annotated commentary, vol 10]. Tokyo: Shūeisha.

Kupchik, J. (2011). A grammar of the Eastern Old Japanese dialects. PhD dissertation, University of Hawai'i at Manoa.

Mizushima, Y. (1972). Kōchū Man'yōshū Azuma uta Sakimori uta [Azuma songs and border guard songs from the Man'yōshū]. Tōkyō: Kasama Shoin.

Mizushima, Y. (1984a). Man’yōshū Azuma uta no kokugogaku-teki kenkyū [A linguistic study of the Azuma songs in the Man'yōshū]. Tōkyō: Kasama Shoin. 
Mizushima, Y. (1984b). Man'yōshū Azuma uta honbun kenkyū narabi ni sōsakuin [Indexes to and research on the original text of Azuma songs in the Man'yōshū]. Tōkyō: Kasama Shoin.

Mizushima, Y. (1986). Man'yōshū zenchū. Kan dai 14. [A complete commentary on the Man'yōshū, vol. 14]. Tokyo: Yūhikaku.

Mizushima, Y. (1996). Kōchū Man'yōshū Azuma uta Sakimori uta: shin zōho kaiteiban [Azuma songs and border guard songs from the Man'yōsh $\bar{u}$ : New reprint with additions and emendations]. Tōkyō: Kasama Shoin.

Mizushima, Y. (2003). Man'yōshū Sakimori uta zenchūshaku [A complete commentary on the Man'yōshū border guard poems]. Tōkyō: Kasama Shoin.

Mizushima, Y. (2005). Man'yōshū Sakimori uta no kokugogaku-teki kenkyū [A linguistic study of the Man'yōshū border guard poems]. Tōkyō: Kasama Shoin.

Mizushima, Y. (2009). Man'yōshū Sakimori uta no kenkyū [Research on the Man'yōshū border guard poems]. Tōkyō: Kasama Shoin.

Nakanishi, S. (1981). Man'yōshū zen yakuchū genbun tsuki (san) [A complete translation of the Man'yōshū with the original text and commentary (vol. 3)]. Tokyo: Kōdansha.

Nakanishi, S. (1983). Man'yōshū zen yakuchū genbun tsuki (yon) [A complete translation of the Man'yōshū with the original text and commentary (vol. 4)]. Tokyo: Kōdansha.

Omodaka, H. (1984a). Man'yōshū chūshaku kan dai 14 [A commentary on the Man'yōshū, Book 14]. Tokyo: Chūōkōronsha.

Omodaka, H. (1984b). Man'yōshū chūshaku kan dai 20 [A commentary on the Man'yōshū, Book 20]. Tokyo: Chūōkōronsha.

Pellard, T. (2008). Proto-Japonic *e and *o in Eastern Old Japanese. Cahiers de linguistique Asie orientale 37(2): 133-158.

Vovin, A. (2005). A descriptive and comparative grammar of Western Old Japanese - Part 1: Phonology, Script, Lexicon, and Nominals. Folkestone: Global Oriental.

Vovin, A. (2009a). A descriptive and comparative grammar of Western Old Japanese - Part 2: Adjectives, verbs, adverbs, conjunctions, particles, postpositions. Folkestone: Global Oriental.

Vovin, A. (2009b). Man'yōshū to Fudoki ni mirareru fushigina kotoba to jōdai Nihon rettō ni okeru Ainu go no bunpu [Strange words in the Man'yōshū and Fudoki and the distribution of the Ainu language in the Japanese islands in prehistory]. Kyoto: Kokusai Nihon Bunka Kenkyū Sentā.

Vovin, A. (2009c). A translation of the Man'yōshū Book 15. Folkestone: Global Oriental.

Vovin, A. (2010). Koreo-Japonica. Honolulu: University of Hawaii Press. 